\title{
ANALYTICAL TOOLS OF ERP-SYSTEMS IN MONITORING THE ENTITY ACTIVITIES
}

\author{
Alla Syrotynska; Nataliia Pozniakovska; Olesia Miklukha
}

\section{National University of Water and Environmental Engineering, Rivne, Ukraine}

\begin{abstract}
Summary. In order to achieve high results with optimal projected costs, the modern business environment requires of management the effective managerial decision-making, which involves continuous monitoring of goal indicators important to assess the direction of enterprise development. The object of the scientists research is theoretical and practical aspects of ERP-systems functioning, but it should be noted that recommendations on ERP application for end-users still remain out of consideration, analytical tools existing in these systems and the peculiarities of their application are not studied sufficiently. Today, the systems of complex enterprise management automation-ERP-systems are widely used in the market of software for business management. Such systems make it possible to calculate the short-term (months) and long-term (years) indicators of enterprise development, as well as compare projected values with actual ones. The functionality of such IS meets the standards of ERP, MRP, $C R M$, and SCM. The introduction of ERP-system changes the management system and the enterprise staff activity management proved by the application of innovative skills of registration, processing, synthesis and analysis of data. The execution of their functions by accountants and top managers in ERP-system involves the use of their professional judgments in accordance with the tasks determined by the increase of the enterprise activity efficiency. They are responsible for the selection of the indicators composition to be analyzed, the formation of strategy for goals achieving, the choice of analysis option, etc. The correctness of setting goals for enterprise development, the selection of the activity results indicators and the methodology for their monitoring is of great importance for business entity management system and increases the efficiency of decision-making. In order to optimize this process, we propose the model of goal indicators and their monitoring in ERP-system making it possible to optimize the management decision-making, increase their efficiency and productivity. The proposed model of goal indicators and their monitoring in ERP-system is the tool for program setting enabling the managers to use new skills for evaluation, monitoring the activity results and making immediate business managerial decisions, to cover the key categories of business development goals, and to engage the responsible individuals of all entity departments into evaluation of the activity results and participation of the management processes which is in conformity with the results of previous investigations.
\end{abstract}

Key words: analytical tools, ERP-system, activity monitoring, indicators, model of goal indicators.

\section{УДК 657.1: 004:047.44}

\section{АНАЛІТИЧНІ ІНСТРУМЕНТИ ЕRР-СИСТЕМ У МОНІТОРИНГУ ДІЯЛЬНОСТІ СУБ'ЄКТА ГОСПОДАРЮВАННЯ}

\section{Алла Сиротинська; Наталія Позняковська; Олеся Міклуха}

\author{
Національний університет водного господарства та \\ природокористування, Рівне, Украӥна
}

\begin{abstract}
Резюме. 3 метою досягнення високих результатів з оптимальними прогнозованими витратами, сучасне бізнес-середовище вимагає від менеджменту ефективного прийняття управлінських рішень, щз передбачає постійний моніторинг цільових показників-індикаторів, важливих для оцінювання напрямів розвитку підприємства. Об'єктом дослідження науковиів є теоретичні та практичні аспекти функиіонування ЕRP-систем. Але слід зауважити, щзо поза увагою залишаються рекомендації 3
\end{abstract}


використання ERP-систем для кінцевих користувачів, недостатньо вивчені аналітичні інструменти, які існують у цих системах, особливості їх застосування. На сьогодні на ринку програмного забезпечення для управління бізнесом активно використовуються системи комплексної автоматизації управління підприємством - ЕRP-системи. Такі системи дозволяють розрахувати короткотермінові (місяиі) та довготермінові (роки) показники розвитку підприємства, а також порівняти прогнозні значення 3 фактичними. Функціональність таких IC відповідає стандартам ERP, MRP, CRM, SCM. Запровадження ERP-системи змінюе систему менеджменту та організаиію роботи персоналу підприємства, щчо виражається у застосуванні інноваційних навичок реєстраџії, опрацювання, узагальнення та аналізу даних. Виконання в ЕRP-системі бухгалтерами та топ-менеджерами свойх функцій передбачає застосування ними професійних суджень відповідно до завдань, які зумовлені зростанням ефективності діяльності підприємства. Вони відповідають за обрання складу показників, які повинні аналізуватись, формування стратегії досягнення цільових показників, вибір варіанта аналізу тощо. Правильність постановки иілей розвитку підприємства, обрання показників-індикаторів результатів діяльності та методики їх моніторингу має важливе значення для системи менеджменту суб'єкта господарювання, підвишує ефективність прийнятих рішень. Для оптимізації иьього проиесу ми пропонуємо модель иільових показників та їх моніторингу в ЕRР-системі, яка дозволить оптимізувати прийняття управлінських рімень, підвищить їх оперативність та ефективність. Запропонована модель цільових показників та їх моніторингу y ERP-системі $\epsilon$ інструментом налагодження програми, зумовлює застосування управлінцями нових навичок з оцінки, моніторингу результатів діяльності та прийняття оперативних рішень з управління бізнесом, охоплює ключові категорії цілей розвитку бізнесу, залучає до оцінювання результатів діяльності та участі в процесах управління відповідальних осіб усіх підрозділів суб'єкта господарювання, що узгоджується з результатами попередніх досліджень.

Ключові слова: аналітичні інструменти, ЕRP-система, моніторинг діяльності, показникиіндикатори, модель изільових показників.

https://doi.org/10.33108/galicianvisnyk_tntu2020.01.159

Отримано 25.01.2020

Introduction. Economic activity is carried out by economic entities in order to achieve economic and social results and profit, and includes risks that may affect its effectiveness. In order to achieve high results with optimal projected costs, the modern business environment requires of management the effective managerial decision-making, which involves continuous monitoring of goal indicators, important to assess the direction of enterprise development. The achievement of high performance is one of the main tasks of management of the business entity, the solution of which can enhance the competitiveness of the enterprise. Today it is impossible without the use of information systems (IS) that can provide comprehensive automation of management support processes.

The analysis of goal indicators involves the implementation of the following steps: 1) the establishment of a list of indicators; 2) establishing their normative values and desired directions of change (possible industry features); 3) the introduction by the user of the list and parameters of the indicators; 4) determination of the actual value of the indicators, which reflects the real state of the entity; 5) the assessment of the correspondence between the normative and actual values of the indicators; 6) formulation of conclusions.

It is necessary to monitor such indicators and their parameters, because the indicators used for evaluation can change their importance and normative or planned values, in accordance with the conditions of the external and internal environment, strategic goals.

Review of the latest research and literature. A number of scientific papers are devoted to theoretical and practical aspects of the application of enterprise management tools, implementation and use of information systems to support managerial decisions (ERP-systems) [1-7].

T. Vasiljeva and E. Berezkina investigated the approaches to managing ERP-projects in order to select the most effective system that would improve the performance of the enterprise. Scientists study the interaction of factors (project and organization related issues, external environment), stages (implementation, roll-out, upgrades, etc.) and project management practices (Waterfall, Agile, etc.) to choose the best systems for designing. T. Vasiljeva and 
E. Berezkina believe that the efficiency of using ERP-systems depends on the programming tools being used inside them, so selecting the best ones is important for project management [1].

T. Vasiljeva and E. Berezkina, summarizing qualitative data and expert assessments, reviewed project management practices to determine the most relevant in the programming of ERP-projects. The researchers presented the results of studying the methodologies used for ERP-systems, classified ERP-projects, and investigated the internal and external factors being important for choosing the project management practice. Based on the research carried out, the matrix of estimation of factors is proposed to choose the optimal design of the ERP-system [1].

The processes for implementing ERP-systems were studied by Guy Janssens, Linda van Moorst, Rob Kusters, Harry Martin [2]. Scientists point out that organizations around the world depend on the effectiveness of ERP-systems that are used to record current transactions and enable enterprises to integrate a wide range of business processes into different functional areas, thus increasing the productivity, efficiency and competitiveness of business. Unlike T. Vasiljeva and E. Berezkina (2018), Guy Janssens, Linda van Moorst, Rob Kusters, and Harry Martin consider the effectiveness of ERP-systems through the peculiarities of their implementation [2].

Tingting Huang and Kazuhiko Yasuda studied ERP life cycle and proposed its conceptual model. Scientists believe that the real life cycle of ERP is the stage after implementation, as this process becomes easier with the emergence of new types of ERPsystems. The conceptual model of ERP life cycle consists of the stages of diffusion, use, expansion and decay phase. Scientists supplement it with two aspects: organization and system that consist of five elements: governance, participation, skills, cost effectiveness, application, and architecture [3].

Bjelland E., Haddara M. also studied the life cycle of ERP, which, in their opinion, consists of the following phases: decision-making, acquisition, implementation, use and maintenance, development, resignation [4]. In this view, the authors are tangent with the statement of Tingting Huang and Kazuhiko Yasuda. Consequently, ERP-project involves the management of change, people, processes and product [4].

The use of information systems as an instrument of accounting and analytical support for business entities, the development of the digital economy and society, the question of reforming accounting and financial reporting based on International Financial Reporting Standards were researched in scientific papers [5-7].

Consequently, the theoretical and practical aspects of ERP-systems functioning are the subject of research of many scientists, but beyond their attention there are recommendations on the use of ERP-systems for end-users, the study of the analytical tools that exist in these systems and the peculiarities of their application are not sufficiently studied as well.

Main purpose of the article is to research theoretical and practical aspects of the ERPsystems functioning, analytical tools that exist in these systems and the peculiarities of their application.

Statement of the problem. The following scientific tasks have been set out to achieve the target goal: to summarize scientific advances on the introduction and use of ERP-systems; to study the changes that implement the introduction of ERP-system on the management system and the organization of work of the enterprise's personnel, to develop the practical recommendations for optimizing the process of making managerial decisions using ERPsystem data through the introduction of the model of goal indicators and their monitoring.

Statements of main issues of the study. Today in the market of software for business management, the systems of complex automation of enterprise management - ERP-systems are widely used. They, in addition to current operations, provide computerization of managerial accounting and budgeting, process planning for resource requirements and performance, 
control and analytical procedures and calculations. Such systems make it possible to calculate the short-term (months) and long-term (years) indicators of enterprise development, as well as compare projected values with actual ones. The functionality of such IS meets the standards of ERP, MRP, CRM, SCM.

Examples of such systems in Ukraine are «Best-5», «Galaxy», «DeloPro», «ERP Virtuoso System», «IS-PRO», «Microsoft Dynamics», configurations based on «1C: Enterprise», «Management of a trading enterprise», «Management of a production enterprise». The German company «SAP» is a leader in the Ukrainian market of enterprise information management systems (EIMS), and since 2017, the Ukrainian EIMS «BAS ERP» has actively been implementing.

Modern ERP-systems are automated information management systems that allow to:

- define goals and criteria for assessing achievements of the structural divisions of the enterprise;

- present the target enterprises in the form of forecasts and plans, while developing a system of indicators that will be used to assess the achievement of objectives, establish conditions, requirements and planning constraints;

- $\quad$ automate the operational accounting of enterprise activity, personnel management and its motivation;

- monitor financial and economic activity;

- calculate and analyze the deviation of the actual results from the planned or typical values;

- formulate management, financial and other reports for external users according to national and international standards.

It should be noted that the introduction of ERP-system changes the management system and the organization of work of the enterprise's personnel, which is expressed in the application of innovative skills for registration, processing, synthesis and analysis of data. Yes, operational documents in the system are created by employees responsible for registering current operations. The functions of accountants consist in checking the registered documents, setting up rules for exercising the checking and conducting registry records, summarizing credentials, developing management, financial and other (non-financial) reporting, monitoring, analyzing and monitoring target indicators.

ERP-system tools change the process of making managerial decisions by top managers of the entity, which is expressed in the use of goal indicators, their analysis and monitoring. The management of the managerial system who are responsible for assessing the achievements of the enterprise should determine the goals and criteria for business development, develop indicators that will analyze the results, establish their planned values and compare them with the actual ones, analyze the deviations, and make optimal management decisions.

Performance of the functions in ERP-system by accountants and top managers involves the use of their professional judgments in accordance with the tasks caused by the increased efficiency of the enterprise. They are responsible for selecting the composition of the indicators to be analyzed, the formation of a strategy for achieving the targets, the choice of the analysis option, etc. The correctness of setting goals for enterprise development, the selection of indicators of the results of activities and the methodology for their monitoring is important for business entity management system and increases the efficiency of the decision- making.

To optimize this process, we propose the matrix of goal indicators (table 1). 
Table 1. Recommended model of goal indicators and their monitoring in ERP-system

\begin{tabular}{|c|c|c|c|c|c|}
\hline $\begin{array}{c}\text { Goal } \\
\text { categories }\end{array}$ & Goal indicators & $\begin{array}{c}\text { Goal achievement } \\
\text { strategy }\end{array}$ & $\begin{array}{l}\text { Responsible } \\
\text { person for } \\
\text { monitoring } \\
\text { indicators } \\
\end{array}$ & $\begin{array}{l}\text { Recommended } \\
\text { option for goals } \\
\text { analysis }\end{array}$ & $\begin{array}{c}\text { Recommended } \\
\text { presentation } \\
\text { of results }\end{array}$ \\
\hline \multirow{6}{*}{ 异 } & $\begin{array}{l}\text { Absolute liquidity } \\
\text { ratio, } \%\end{array}$ & $\begin{array}{c}20-25 \% \text {, recoupment } \\
\text { within the acceptable } \\
\text { range }\end{array}$ & \multirow{6}{*}{$\begin{array}{l}\text { Financial } \\
\text { Director, } \\
\text { Chief } \\
\text { Accountant }\end{array}$} & \multirow{12}{*}{$\begin{array}{c}\text { - Type of } \\
\text { analysis: } \\
\text { - measurement } \\
\text { of the current } \\
\text { state; } \\
\text { - Period: } \\
\text { quarter; } \\
\text { - Periodicity: } \\
\text { month; } \\
\text { - Method for } \\
\text { calculating } \\
\text { values: amount }\end{array}$} & \multirow{12}{*}{ 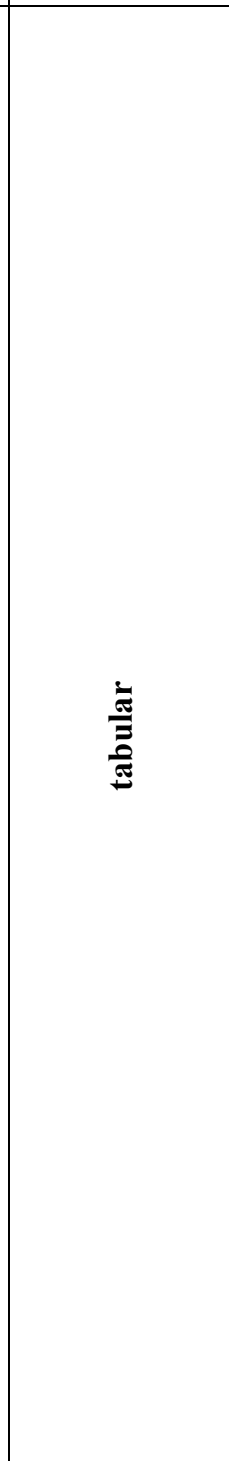 } \\
\hline & $\begin{array}{l}\text { Current factor } \\
\text { liquidity, } \%\end{array}$ & $\begin{array}{l}150-200 \% \text {, } \\
\text { recoupment within } \\
\text { the acceptable range }\end{array}$ & & & \\
\hline & Return on equity, $\%$ & Value maximization & & & \\
\hline & $\begin{array}{c}\text { Profitability of } \\
\text { products, goods, } \\
\text { works, services, \% }\end{array}$ & Value maximization & & & \\
\hline & $\begin{array}{l}\text { Operating factor of } \\
\text { fixed assets, } \%\end{array}$ & Value minimization & & & \\
\hline & $\begin{array}{l}\text { Turnover of current } \\
\text { assets, days }\end{array}$ & Value minimization & & & \\
\hline \multirow{3}{*}{ 递 } & $\begin{array}{c}\text { Share of receivables } \\
\text { in property, } \%\end{array}$ & $\begin{array}{l}20 \%, \text { value } \\
\text { minimization }\end{array}$ & \multirow{3}{*}{$\begin{array}{l}\text { Financial } \\
\text { Director, } \\
\text { Chief } \\
\text { Accountant, } \\
\text { Head of } \\
\text { Marketing } \\
\text { Department }\end{array}$} & & \\
\hline & $\begin{array}{c}\text { Ratio of receivables } \\
\text { and accounts payable, } \\
\text { UAH/UAH }\end{array}$ & $\begin{array}{l}\text { 1, content within the } \\
\text { acceptable range }\end{array}$ & & & \\
\hline & $\begin{array}{c}\text { Coefficient of } \\
\text { independence, } \%\end{array}$ & $\begin{array}{c}50 \% \text {, recoupment } \\
\text { within the acceptable } \\
\text { range }\end{array}$ & & & \\
\hline 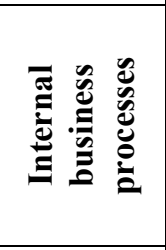 & $\begin{array}{l}\text { Coefficients of the } \\
\text { goals categories } \\
\text { «Finance» and } \\
\text { «Customers», } \\
\text { calculated by } \\
\text { divisions }\end{array}$ & $\begin{array}{l}\text { According to the } \\
\text { categories of goals } \\
\text { «Finance» and } \\
\text { «Customers» }\end{array}$ & $\begin{array}{l}\text { Heads of } \\
\text { divisions }\end{array}$ & & \\
\hline \multirow{2}{*}{ 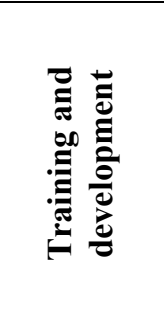 } & $\begin{array}{c}\text { Share of workers } \\
\text { with higher } \\
\text { education, } \% \\
\end{array}$ & Value maximization & \multirow[b]{2}{*}{$\begin{array}{l}\text { Head of HR } \\
\text { department }\end{array}$} & & \\
\hline & $\begin{array}{l}\text { Share of employees } \\
\text { with certificates of } \\
\text { additional courses, } \\
\text { knowledge and } \\
\text { kills, \% }\end{array}$ & Value maximization & & & \\
\hline
\end{tabular}

The model contains indicators of stimulators that need to maximize the values (positively evaluated with growth), and de-stimulators that need to minimize the values (positively estimated at decrease), as well as regulatory ratios that need to be kept within the acceptable range.

Options for the analysis of goal indicators in modern programs are allocated in the section «Target Monitor». Among the possible definitions of the type of analysis, we propose to choose «Measurement of the current state». Other types of analysis: dynamics of change; component comparison (structure); component comparison (dynamics); comparisons with the previous period can be selected additionally, if necessary, to be detailed.

The method of calculating the values «Sum of the growing summing up» for parametric analysis is not desirable, therefore we recommend the «Sum» method.

In accordance with the stated goals, the indicators selected should be grouped into the «Target Monitor», which is adjusted accordingly to the needs of the responsible person. This will allow quick access to data and provide business entity with necessary information to make 
operational management decisions. The user should set the parameters of the indicators monitoring, depending on the objectives of management, which includes:

- $\quad$ selection of set of indicators;

- adjustment of parameters of grouping of indicators (according to the categories of enterprise goals, according to the state: inappropriate state, acceptable state, the goal is reached, the state is not defined, calculated with error);

- $\quad$ setting the parameters of data presentation;

- determining the period of information auto update.

Thus, the proposed model of goal indicators and their monitoring in ERP-system will optimize the adoption of management decisions, increase their efficiency and productivity.

T. Vasiljeva and E. Berezkina [1], Guy Janssens, Linda van Moorst, Rob Kusters, and Harry Martin [2] point out that ERP-systems engage the majority of enterprise units, they represent premium projects, so the effectiveness of their use and implementation is important for businesses. We agree with the statements of the above-mentioned scholars on the relevance of studying the tools of ERP-systems to improve the management of the entity. The proposed model of goal indicators and their monitoring in ERP-system is a tool for establishing the program for conducting an operational analysis of business operation results that will increase the efficiency and timeliness of management decisions.

Tingting Huang and Kazuhiko Yasuda suggested adding the organization and system that consists of management, participation, skills, cost effectiveness, application, and architecture to ERP conceptual model [3]. The model of the goal indicators developed by us is an integral part of the management system of business entity in ERP-project, aimed at increasing the efficiency of management of the enterprise, whose participants are the management structure of the organization. The use of ERP-system target models results in the use of new skills by managers to evaluate, monitor performance and make operational decisions on business management.

It is worth agreeing with Tingting Huang and Kazuhiko Yasuda [3] and Bjelland E., Haddara M. [4] that ERP is not just software, but a system for organizing the information of business entity used by most divisions firms, has management tools designed to optimize costs and is designed for a specific application. The proposed model of target indicators and their monitoring in ERP-system covers the key categories of business development goals, involves the assessment of the results of the activity and participation of the responsible persons of all entities of the economic entity in management activities.

Conclusions. The article presents the results of the investigations concerning the functioning of ERP-systems in relation to the use of analytical tools in monitoring the business entity activities. The execution of their functions by accountants and top managers in ERPsystem involves the use of their professional judgments in accordance with the tasks determined by the increase of the enterprise activity efficiency. They are responsible for the selection of the indicators composition to be analyzed, the formation of strategy for goals achieving, the choice of analysis option, etc. The correctness of setting goals for enterprise development, the selection of the activity results indicators and the methodology for their monitoring is of great importance for business entity management system and increases the efficiency of decisionmaking.

To optimize this process, we propose the model of goal indicators and their monitoring in ERP-system, containing indicators of stimulators that should maximize, and stimulators to minimize the values and regulatory factors that have to be maintained within the acceptable range. In accordance with the stated goals, the selected indicators are recommended to group on the monitor the target values of ERP-system enabling quick access to data and provide top managers of the firm with the necessary information for the adoption of operational management decisions. 
The model of target indicators developed by us and their monitoring should be used to solve the problems of the enterprise management system, which determines its practical value. The results presented in this paper will be the basis for further theoretical and practical investigations concerning implementation and use of ERP-systems, their analytical tools for improving the efficiency of the entity management system.

\section{References}

1. Vasiljeva T., Berezkina E. Determining Project Management Practices for Enterprise Resource Planning System Projects. Journal of Enterprise Resource Planning Studies. 2018. Vol. 2018. Article ID 927123. DOI: 10.5171/2018.927123. URL: https://ibimapublishing.com/articles/JERPS/ 2018/927123/927123.pdf. https://doi.org/10.5171/2018.927123

2. Guy Janssens, Linda van Moorst, Rob Kusters, Harry Martin. An expert-based taxonomy of ERP implementation activities. Journal of Computer Information Systems. 2018. DOI: 10.1080/ 08874417.2018.1429958. URL: https://www.tandfonline.com/doi/full/10.1080/08874417.2018. 1429958. https://doi.org/10.1080/08874417.2018.1429958

3. Tingting Huang, Kazuhiko Yasuda. Reinventing ERP Life Cycle Model: From Go-Live To Withdrawal. Journal of Enterprise Resource Planning Studies. 2016. Vol. 2016. Article ID 331270. DOI: 10.5171/2016.331270. URL: https://ibimapublishing.com/articles/JERPS/2016/331270/331270.pdf. https://doi.org/10.5171/2016.331270

4. Bjelland E., Haddara M. Evolution of ERP Systems in the Cloud: A Study on System Updates. Systems. 2018. № 6 (22). DOI: 10.3390/systems6020022. URL: https://www.mdpi.com/2079-8954/6/2/22/htm. https://doi.org/10.3390/systems6020022

5. Syrotynska A. Information systems and technologies in the system of accounting and analytical support of business entities. Accounting and analytical support of economic entities in the conditions of European integration: monograph. Rivne: NUWM, 2019. P. 122-133. URL: http://ep3.nuwm.edu.ua/.

6. Pozniakovska N., Zybilevich S., Miklukha O. and other Effectiveness of public sector entities in the digital competencies development. Accounting and analytical support of economic entities in the conditions of European integration: monograph. Rivne: NUWM, 2019. P. 154-162. URL: http://ep3. nuwm.edu.ua/14323/1/.

7. Pozniakovska N., Zybilevich S., Miklukha O. and other Reforms of accounting and financial reporting in Ukraine: during 20 years. Accounting and analytical support of economic entities in the conditions of European integration: monograph. Rivne: NUWM, 2019. P. 8-26. URL: http://ep3.nuwm.edu.ua/ 14323/1/.

\section{Список використаної літератури}

1. Vasiljeva T., Berezkina E. Determining Project Management Practices for Enterprise Resource Planning System Projects. Journal of Enterprise Resource Planning Studies. 2018. Vol. 2018. Article ID 927123. DOI: 10.5171/2018.927123. URL:https://ibimapublishing.com/articles/JERPS/2018/927123/927123.pdf. https://doi.org/10.5171/2018.927123

2. Guy Janssens, Linda van Moorst, Rob Kusters, Harry Martin. An expert-based taxonomy of ERP implementation activities. Journal of Computer Information Systems. 2018. DOI: 10.1080/08874417.2018.1429958. URL: https://www.tandfonline.com/doi/full/10.1080/08874417.2018. 1429958. https://doi.org/10.1080/08874417.2018.1429958

3. Tingting Huang, Kazuhiko Yasuda. Reinventing ERP Life Cycle Model: From Go-Live To Withdrawal. Journal of Enterprise Resource Planning Studies. 2016. Vol. 2016. Article ID 331270. DOI: 10.5171/2016.331270. URL: https://ibimapublishing.com/articles/JERPS/2016/331270/331270.pdf. https://doi.org/10.5171/2016.331270

4. Bjelland E., Haddara M. Evolution of ERP Systems in the Cloud: A Study on System Updates. Systems. 2018. № 6 (22). DOI: 10.3390/systems6020022. URL: https://www.mdpi.com/2079-8954/6/2/22/htm. https://doi.org/10.3390/systems6020022

5. Сиротинська А. Інформаційні системи і технології в системі обліково-аналітичного забезпечення суб'єктів господарювання. Обліково-аналітичне забезпечення суб'єктів господарювання в умовах євроінтеграції: монографія. Рівне: НУВГП, 2019. С. 122-133. URL: http://ep3.nuwm.edu.ua/14323/1/.

6. Позняковська Н., Зубілевич С., Міклуха О. та ін. Ефективність суб’єктів державного сектору в умовах розвитку цифрових компетенцій. Обліково-аналітичне забезпечення суб'єктів господарювання в умовах євроінтеграції: монографія. Рівне: НУВГП, 2019. С. 154-162. URL: http://ep3.nuwm.edu.ua/14323/1/.

7. Позняковська Н., Зубілевич С., Міклуха О. та ін. Реформи бухгалтерського обліку та фінансової звітності в Україні: 20 років поспіль. Обліково-аналітичне забезпечення суб'єктів господарювання в умовах євроінтеграції: монографія. Рівне: НУВГП, 2019. С. 8-26. URL: http://ep3. nuwm.edu.ua/14323/1/. 